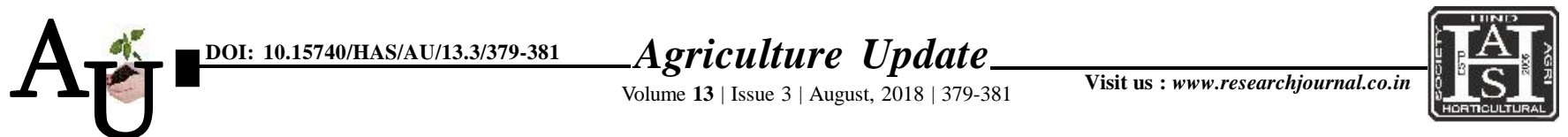

口 e ISSN-0976-6847

\title{
Research Note: Learning experience of marginal farmers in sugarcane cultivation
}

\section{Balamurugan}

Article Chronicle : Received :

02.02.2018;

Accepted :

28.07.2018

KEY Words:

Marginal farmers, Learning experience

Author for correspondence :

V. Balamurugan Department of Agricultural Extension, Faculty of Agriculture, Annamalai University, Annamalai Nagar (T.N.) India
SUMMARY : The effective learning experience can be had effective learning situations provided by a skillful instructor who knows what he wants, who has the materials to accomplish his goals and the skills to use them effectively. The study was conducted in Cuddalore district of Tamil Nadu. A total number of ten sugarcane technologies with technical units were selected for the study. The result of the study showed that the marginal farmers possessed low level of learning experience. The learning experience may be further enhanced by majority of the marginal farmers to prefer personal localite channels for getting information.

How to cite this article : Balamurugan, V. (2018). Learning experience of marginal farmers in sugarcane cultivation. Agric. Update, 13(3): 379-381; DOI : 10.15740/HAS/AU/13.3/379-381. Copyright@2018: Hind Agri-Horticultural Society. 